August 1996

version $\# 1$

Prepared for Egon-Sohmen Symposium 1996

on "Privatization at the Turn of the Century"

Budapest, Sept. 6-7, 1996

\title{
WHEN THE STATE CHANGES ITS MIND: THE PUZZLE OF DISCONTINUTIY IN GOVERNMENT CONTROL OF ECONOMIC ACTIVITY
}

\author{
by
}

Thráinn Eggertsson

Hoover Institution, Stanford University

Stanford, California 94305

USA

Tel: 1/415-723 2672

Fax: 1/415-723 1687

Email: thrainn@leland.stanford.edu 
Thráinn Eggertsson

Version \#1, August 1996

\section{WHEN THE STATE CHANGES ITS MIND: \\ THE PUZZLE OF DISCONTINUITY IN GOVERNMENT CONTROL OF ECONOMIC ACTIVITY}

\section{Government control as a dependent variable}

By its allocation of the right to control scarce resources, the state shapes the distribution of wealth, economic organization, and economic performance over time (North, 1981, 1990). The locus of control within the state itself, for instance on the local-central axis, can have significant impact on economic systems (Weingast, 1995; Ostrot , 1990), but here I am concerned with the public-private divide. The publicprivate division of control has several dimensions that are relevant for economic performance, including:

(1) The distribution of the national dividend. Issues such as the share going to urban elites in a developing country or to the nobility and clergy in France under the old regime; the share retained by farmers under forced industrialization in the Soviet Union, or by landed property in England at various times; or unearned income withheld in social democratic Europe.

(2) The structure of control in production. Regimes governing, for instance, the provision of infrastructure; the rights of private property; the right to set prices, quantity, quality of inputs, and levels output in production; conditions of entry and exit from an industry; rights of labor, including rights to organize and disrupt production; the promotion of specific firms, industries, and regions; direct state involvement in production, distribution, and exchange; nationalization.

(3) Enforcement, and the gap between nominal and effective 
systems of control. Does rule of law prevail or is the state unpredictable and predatory; are agents of the state corrupt; do official rules have an informal aura of legitimacy?

(4) Macroeconomic regulation of the economic system, including monetary and fiscal controls; trade controls; price controls and incomes policy; central planning.

Economic analysis prescribes or predicts public policy from either of two perspectives, which I label the remedial and redistributive modes or explanations. The remedial mode abstracts from the politics of distributional struggles and assumes that the state's main aim is to maximize global net wealth. The state, therefore, is preoccupied with macro-stability and performance (prices, employment, balance of payments, growth), and prevention of deadweight losses, a problem usually attributed to missing or imperfect markets, for instance markets for clean air and water, greater output by monopolies, or occupational safety (Atkinson and Stiglitz, 1980). Questions of distribution usually enter exogenously, if at all. The redistributive mode explains government control in terms of relative power, political processes, and maximization of wealth by various groups (Alt and Shepsle, 1990; Buchanan et al., 1980; Moe, 1990; Mueller, 1989)

I am concerned in this essay with those moments in history when the state appears to change its mind; with historical changes in government control along the public-private divide, particularly with discontinuity in the control process: large steps or reversals of trends. My discussion refers primarily to the experience of Western industrial powers. The following section briefly surveys historical trends in government control, but before entering that discussion I want to consider how the notion of discontinuity sits with the remedial and redistributive modes of economic analysis.

Discontinuity and the remedial mode

Discontinuity in government control poses something of a puzzle for remedial 
explanations of control regimes, if we assume (a) that fundamental policy targets remain stable over time, and (b) that those in power share a common vision of economic relationships - share a policy model. With consensus on policy models, and with stable targets or goals, changes in government control are driven by structural changes in the economy, which usually are gradual rather than lumpy, natura nonfacit saltum. And gradual structural changes do not require large lumpy changes in control regimes, but suggest piecemeal revisions. ${ }^{1}$ These tight assumptions, however, do not exclude reversals of long-term trends in government control. One can imagine an economy first evolving through an industrial structure that is plagued by costly spillover effects, instability, and monopoly that, according to prevailing policy models, only the state can control effectively, and then emerge in an era of new technology and new structures that require less remedial public control. Vietor (1994, pp. 18-20), for instance, discusses how in the late 1960s new technology began to undermine natural monopoly in telecommunications in the United States. New technology, as it emerges, also can give the opposite impression, that central control is the most effective way of creating wealth.

My emphasis on gradual structural change needs some qualification. Events such as wars sometimes call forth massive investment by the state and private actors in research and development. War-related inventions, usually with a considerable lag, then hit the peace-time economy, and create a discontinuous structural change. A large number of innovations clustered in the Second World War, and were commercialized 15-20 years later. These innovations lowered entry barriers (microwave technology), increased capacity (wide-bodied aircraft), and changed economies of scope (electronic transfer of funds, automatic teller machines), and affected perceptions about the need for remedial regulation (Vietor, 1990, p. 17).

The assumption of stable targets of government policy and shared policy models

Admittedly, economies of scale in reform might make it practical not to fix economic problems as soon as they are recognized, but wait and periodically engage in omnibus reforms. On the other hand, it is just as likely that massive reforms involve diseconomies of scale. 
obviously is unrealistic. The distribution of power is not stationary, the coalitions that control the state change over time, and so do the targets of public policy. In addition, economic policy in a world of scarce information and knowledge is a walk in the dark. Key actors disagree not only on policy targets, but also on appropriate means for reaching any particular target: they disagree on the policy model. Even when a particular regime produces satisfactory results, actors entertaining different policy models need not agree how the satisfactory results came about, or under what circumstances good performance can be repeated. The intellectual history of the gold standard, which in the late 19th and early 20th centuries linked the monetary system of several major countries with fixed exchange rates, well illustrates the walk-in-the-dark metaphor. Explanation offered by specialists at the time and later (The Cunliffe Report 1918; McCloskey and Zecker, 1976; Ford, 1964), differ on why the system worked well 1870-1913 "in the sense of eliminating balance of payments imbalances without exchange rate changes in a rapidly changing world economy (Ford, 1989 p 197)." Besides, the apparently disastrous reintroduction of the system in the interwar period suggests that both academic specialists and men of power have incomplete policy models (Moggridge 1989).

My emphasis on the incompleteness and diversity of policy models, should not hide the fact that the models of different actors tend to cluster, and that these clusters change over time, as we see by comparing European opinions during the heyday of liberalism in the mid-19th century, and policy views a century later. Toward the middle of the 20th century, the main clusters of policy models had moved along the public-private axis away from liberalism to greater state involvement. In this latter period, many of those who were morally or politically opposed to the Soviet Union saw central planning or central management as perhaps the most effective set of instruments for generating rapid economic growth. Even the British Conservative Party had a statist wing. In his 1938 manifesto, The Middle Way, Harold Macmillan, a member of the party and later its prime minister, lists various" services and industries that he sees ripe for nationalization. Additionally, 
Macmillan was concerned about the high levels of malnutrition in British cities. He thought that private wholesalers and shops were incapable of providing good food at a price which working-class mothers could afford. Under Macmillan's plan, bread and margarine would have been delivered to the housewife's door by an organization resembling the Post Office. High technology National Bakeries would be built in order to secure economies of scale, although the production and distribution of scones and fancy cakes would remain in private hands (Singleton, 1995, p. 19).

If policy models change relatively rapidly, discontinuous change in public policy is possible, even when there are no fundamental changes in social goals or political power. If ideas travel fast (as Keynesian economics did), new policy views can spread rapidly across major political parties, and even across whole regions of the world. Of course, economic reforms generally are not neutral in terms of the distribution of wealth, but, all the same, a major revision of policy models sometimes transcends redistributive politics. If most policy analysts reject the existence of a long-run trade-off between inflation and unemployment (the Phillips Curve), the question whether we should settle for little inflation and high unemployment, or low unemployment and high inflation becomes irrelevant. A similar, but less clear-cut, argument can be made about oscillations of policy models between central control and decentralization. In the immediate post-Soviet period, few political interests see the reintroduction of central management or central planning as their best strategy.

\section{Discontinuity and the redistributive mode}

If the discussion so far suggests that political struggle and redistribution have little to do with discontinuity in public policy, that was not my intention. Although the 
fundamental economic forces that influence major political change normally move slowly and smoothly, political change itself tends to be discontinuous. And political coalitions vary, not only in their demands on wealth, but also in their basic models of economic relationships. Economic decline in an industry, a region or a country, population growth, expansion of the urban working class, or an increase in the relative importance of service workers usually generate a smooth time series, but associated political developments often have sharp turning points. Expansion of the franchise and other reforms of electoral systems, revision of internal procedures in legislatures, election results, coups and rebellions often produce rapid swings of the public policy pendulum, or even cycling, as was the case with the British iron and steel industry, which went through two rounds of nationalization and denationalization in the period after the Second World War (Singleton, 1995). Explanations based on redistribution, however, require a theory of the state.

So long as economics restricts its analysis of government control by assuming fixed goals (such as global wealth maximization) and secure initial endowments, a theory of political processes is unnecessary. Once attempts are made to explain government control in terms of struggle over distribution, a theory of the state is required. The recent move into political economy and the redistributive mode was motivated partly by apparent paradoxes: Why do dictatorships, with their seeming unlimited political power, often design control regimes that waste resources and bring economic decline? Why does a democratic state grant rights to small interest groups, when these rights bring deadweight losses and hurt a large majority of voters? In answering such questions, the new approach brought together (a) wealth maximizing behavior by various factions and individuals, (b) costly information, and (c) various processes for making political decisions (Mueller, 1989; Olson, 1971). The new redistributive explanations usually see transaction costs and lack of information as the root of apparently irrational economic organization. (Eggertsson, 
1990). ${ }^{2}$

We should not forget, however, that remedial and redistributive explanations of government behavior are in fact complements rather than substitutes; political coalitions that control the state maximizes net wealth by simultaneously considering efficiency and redistribution. However, the marriage of political manipulation and transaction costs, often assigns a secondary role to the remedial mode (North, 1993; Weingast, 1993). Rulers, who share essentially the same policy model of pure economic relationship and similar economic resources, but operate in different political systems and deal with different coalitions, may set up radically different economic organization. The new institutionalism usually explains poor economic performance (slow growth or stagnation), not as the result of incompetent modeling of economic relationships, but as the outcome of particular political relationships. In a society that lacks trust and commercial morality, where the rule of law does not constrain the actors, where political checks and balances are weak, and where enforcement of third party exchange is unreliable, control structures that are optimal for a ruling coalition may bring poor global economic results. The basic economic policy model plays only a secondary role in such bleak stories. In principle, political reform alone, based on fundamental changes in political and social structures, could introduce discontinuity ${ }^{3}$ in regulatory regimes and enormously improve economic performance (North and Weingast, 1989). The political factions in a-declining economic system know that an alternative form of economic organization could improve global economic results, but they cannot make binding agreements about sharing wealth and power under a new regime, and, therefore, prefer the status quo.

2 Scarce information and transaction costs protect politicians in a democracy from the wrath of their voters, who are rationally ignorant; and the same forces give partial protection to the agents and subjects of a dictator and shield them from her inquisitive eye.

3 There are exceptions to this view, particularly Douglass North's long-standing interest in the way that actors model their world, as reflested in their idoobry and shared mental models (North, 1993; Denzau and North, 1994). 
The concept of information costs has pervaded not only political economy and the economics of institutions, but it also has enriched traditional economics and given it new concern with the logic of organization (Milgrom and Roberts, 1992). Therefore, it is appropriate to pause here and consider, whether we now have all the tools required for explaining the evolution of public policy over time, including various types of discontinuity. In my view, current analytical approaches suffer from paying only minimal attention to two issues: the notion of incomplete and variable policy models, already mentioned, and the related issue of control dynamics, the dynamics of regulatory regimes.

\section{Incomplete policy models}

Although economic theory increasing recognizes information scarcity, it usually assumes that correct policy models are available for those who have the incentive to discover them (and the 'correct model' usually is represented by prevailing economic theory or the views of a particular school of thought). In this view, some actors have a complete picture of the relevant economic relationships (because they have low cost of information or strong incentives to find out), others are less interested and economize by relying primarily on persuasion, and, therefore, are vulnerable to misinformation. For instance, ordinary voters or consumers who support (reject) protectionism in international trade are said to do so because special interest has caught their ear. For those who care to invest, however, a correct model of free trade and protectionism is available.

The historical evidence suggests, however, that even specialists and experts rely on incomplete models of social systems. As I have emphasized, historical change in regulatory regimes involves more than shifts in political power, new types of misinformation campaigns, or new technologies and industries that demand new forms of control and organization. Independent shifts in policy models of experts and the public can be an important source of change. When clusters of policy models shift in the same direction, for instance, on the public-private axis, the rulemaking behavior of various coalitions moves in the same direction. Following such 
shifts, we observe that various redistributive coalitions switch to a new policy mode and use new types of instruments to reach their goals.

The dynamics of regulatory regimes

The analytical literature also has little to say about another complex issue: the dynamics of regulatory or control regimes and their path over time. When policy makers using incomplete models design regulatory regimes, such as rent control, a social service, or industrial policy, they set in motion forces that, sooner or later, may have unexpected and unwanted consequences. Unexpected and unwanted results are not a serious matter for those who set the rules, if they either can mend their systems, or swiftly abandon them. For various reasons, however, both technical and political, regulatory regimes may become path dependent and evolve from bad to worse, even for decades, before they collapse or finally are abandoned.

Before continuing my discussion of incomplete policy models and the evolution of control regimes, I pause now to take a quick look at the recent history of government control in Europe and North America, emphasizing long trends and discontinuity.

\section{Long waves and discontinuity in government control of the economy}

Generalizations about historical trends shared by regions of the world are hazardous, but, bravely or foolhardily, many scholars looking back over two centuries of European and North American economic history discern long waves of centralization and decentralization, each wave lasting approximately a century. The various contributions in volume VIII of The Cambridge Economic History of Europe (Mathias and Pollard, 1989), which deals with the development of economic and social policies in the industrial economies, tend to support the idea of long waves in government control. Schremmer (1989, p. 362) provides crude quantitative evidence in a figure showing changes in the share of central government expenditure in gnp. Series for Britain and France, which extend back to the 1780s, are U-shaped, and bottom out somewhere around the middle of the 19th century, after falling by about one-half from the previous high of mercantilism and mutual warfare. The French hit 
their low point earlier than the British. In the 1910s, both series have returned to the levels of the 18th century. Also, Prussia and the German Reich show a sharp increase in the ratio of central government spending to gnp, beginning in the last quarter of the 19th century.

The work of Adam Smith, Jean-Baptist Say, James Mill, and Ricardo, the American Declaration of Independence in 1776, the. French Revolution 1789, the Anglo-French commercial treaty of 1786 symbolize the emergence of dominant clusters of laissez-faire or liberal policy models (Bairoch, 1989, pp. 4-5). However, the long liberal wave contains much variety, and more state intervention (especially at the local level) than many people assume.

Britain moved toward free trade late in the 18th century, the trend was interrupted by the French wars, but culminated in the repeal of the Corn Laws, 1846, which marked the beginning of a free trade era in Britain that lasted until 1914 (Bairoch, 1989, p. 13). The other countries of Western Europe and the United States leaned more toward protectionism than Britain, the world's industrial leader. The phase of European free trade was short, the period 1846-1860 (Bairoch, 1989, pp. 36-50). Prior to World War II, the United States followed a policy of protectionism, except for a phase of liberalism or moderate protectionism that lasted from 18461861 (Bairoch, 1989, p. 140). Yet the historical evidence makes clear that the emerging industrial nations untied the knots of mercantilism, put few restraints on private property, released market forces, and encouraged competition - if not internationally, then domestically or within free-trade zones, such as the German Zollverein. The direct role of the state in production, distribution, and exchange was minimal, compared with earlier and later periods, and, when the state was active, the activity generally was concentrated at the local rather than national level,which is particularly relevant for America (Letwin, 1989).

The strong move toward greater state control in the industrial countries, which began late in the 19th century and early in the 20th century, reflected not only shift $\therefore$ in political power from the middle to the working class, which the state gradually enfranchised, but fundamental revision of policy models as these nations grappled 
with new forms of industrial organization and unfamiliar economic realities. ${ }^{4}$ Industrialization had brought new problems and new opportunities. Among new problems were rapid decline and dislocation in agriculture, industrial accidents, serious spillover effects such as pollution, the dissolution of traditional rural social security networks, uncertainty about the role of women and children in industrial society, low educational level of the labor force relative to the new production techniques, lack of infrastructure services for industry and of service utilities and housing for fast growing urban areas.

The opportunities of the industrial age included rapid increase in wealth, and economies of scale in many of the new activities, which at this time of bewildering change gave credence to claims by political entrepreneurs and Utopia peddlers that the end of scarcity was near. Improvement in communication and transportation, the concentration of economic activity in urban areas, and a huge increase in the scale of production suggested opportunities for central planning. It now seemed possible, that some form of central direction by the state could accelerate industrialization and, at the same time, bring the unruly process under control. Ronald Coase (1991) reports being perplexed in 1931 by the apparent conflict between a denial of the possibility of central planning and the current success of large corporations, and he puzzled why the price system could not provide the coordination rendered by large corporations:

The Russian Revolution had taken place only fourteen years earlier. We knew then very little about how planning would actually be carried out in a communist system. Lenin had said that the economic system in Russia would be run as one

\footnotetext{
4 In Britain as late as 1831, the electorate was less than half a million in a population of 14 millions. The Reform Act of 1832 opened Parliament to the business world, but the working class entered via a second Reform Act of 1867, which gave the vote to twothirds of adult males. Finally, an act of 1918 opened the vote to males over 21 and women over 30 (Checkland, 1989, pp. 608-628).
} 
big factory. However, many economists in the West maintained that this was an impossibility. And yet there were factories in the West and some of them were extremely large (Coase, 1991, p. 7).

Rational actors respond to new social structures by adjusting their policy models, but the structure of the emerging industrial society was poorly understood, an unprecedented phenomenon. If measurement were possible, it probably would show increased variance in policy models entertained by leaders of public opinion as the 19th century wore on. Early in the twentieth century policy models favored by leaders in Europe and North America spanned a spectrum from a regulated decentralized market economy, through a mixed market system with a centralized industrial policy, to full state control of production and central planning. However, statist solutions won the day. America introduced extensive regulations of many of its industries, especially infrastructure service industries, whereas Europe nationalized many of these industries (Vietor, 1990). National governments in American and Western Europe assumed responsibility for the health and wellbeing of their citizens, with Europe taking a larger step toward a welfare state. And following an intense industrialization debate, in 1928 the leaders of the Soviet Union embarked on a massive centrally managed program of forced industrialization (Davies, 1989).

In the 1970s and 1980s a trend away from state control became apparent. Hopes for the effectiveness of central planning dwindled, and so did belief in state sponsored industrial policy. Even France disemboweled its once admired system of indicative planning, beginning in 1976 with the 7th Plan. (Hall, 1986, p.185). The USA entered a phase of deregulation of various infrastructure service industries, and in Britain the Thatcher government began a move toward liberalism in 1979. By the 1980s, few people believed that state ownership of enterprises was an effective way to achieve economic efficiency, financial accountability, restructuring, and better work environment. History seemed to support the raw statement by the Tory 
pamphleteer who in 1949 wrote:

The Socialists were never more wrong than when they believed that nationalization would send their miners sprinting to the pit-head and keep them slogging all day long as merrily as the Seven Dwarfs (Singleton, 1995, p. 25).

As public ownership and various regulations of private industry lost their support, the popularity of decentralized solutions and market-oriented control systems rose. The collapse of the Soviet system in 1989 crowned these developments.

The discontinuity in government control in the last quarter of the twentieth century in many ways is the most striking development since the move toward liberalization 200 years ago, and it raises several questions:

(a) Is the 1970s-1980s discontinuity the beginning of a fundamental reversal of the previous century-long trend toward public control? Are the advanced economies of the world headed toward a new age of liberalism, riding a downward curve of steadily reduced public control?

(b) What forces brought about the changes that we already have seen? In particular, did revision of policy models play and important independent role in recent reversals of policy, or does the explanation rest entirely with shifts in political power, and changes in industrial structure and technology?

My answer to the first set of issues is brief. I tackle the second set of questions in the following section.

My prognosis is mixed. There are clear signs in the last decade of the 20th century that certain forms of state control. espresially central mangement and porbit enterprise in most fields, no longer enjoy support as effective instruments of policy. 
Additionally, in many quarters there is a new sense that various forms of regulation of industry degenerate over time and produce unexpected and unwanted results, without reaching desired goals. The rejection of regulation, however, often is linked with specific industries where regulation is thought to have failed, but there still remains strong demand for state control of consumer and worker safety, for public solutions to environmental issues, and for strict regulation of general operations in various industries, such as finance. Although the industrial democracies have deregulated various industries and sold public enterprises, they also have introduced a large number of new regulations. In the aggregate, the trend is not clear. The lessons from the Third World are mixed. In Squth-East Asia several growthoriented, non-democratic governments have made economic miracles by relying both on the market and state-sponsored industrial policy, in other developing countries economic leadership by the state has brought disasters (Root, 1996).

In sum, except for a shift away from central management, direct state involvement in production, distribution and exchange, and a greater recognition than before of information and incentive problems in economic life, it is by no means clear at this point of transition that the industrial democracies are accelerating toward less and less state involvement in the economy.

\section{The policy model as a dependent variable}

My main point in this essay is that changes in public policy are caused not only by fundamental changes in technology, industrial organization, and political power, but also by independent shifts in policy models shared by clusters of actors. The importance of shifts in policy models increases with the time dimension of our analysis, and the study of historical trends in state involvement in the economy will benefit if we were able to explain why people change their views about the relationship between means and ends in social systems.

Experience as proxy

Common sense suggests that people change their views of the relationship between 
means and ends in social policy because they draw conclusions from their experience with social arrangement, and because they are influenced by others. In addition, people draw on the existing stock of knowledge. The logic of specialization applies here as in other activity. For various reasons, some actors specialize in different aspects of the social system and offer their knowledge to others, but non-specialists base their models on crude proxies and persuasion. Yet, even specialists often have poor understanding of complex social systems and rely on proxies and signals, and, when systems or regimes seriously malfunction or crash, there is a propensity to pursue different approaches, even in areas only indirectly linked to system failures.

Sudden reversals regimes, which are shared by a broad range of political interests and observed roughly simultaneously in several countries, suggest that the changes are driven, at least partly, by shared experience or events that send strong signals. In mixed market economies, standard business cycles may create correlated cycles of alternating centralized and decentralized policy models. If severe economic crashes occurred regularly, say, every fifty or one hundred years, they conceivably could contribute to long cycles of regulation and deregulation, but the case for long business cycles, Kitchin, Juglar, Kondratieff and the rest, remains to be proven.

In general, good performance is likely to create trust in a dominating policy model, and poor performance generates the opposite reactions. Government planning in the First and Second World Wars, which mostly was perceived as successful, serious economic depressions late in the 19th century, the Great Depression of the 1930s, and apparent success with central planning in the Soviet Union were proxies that pushed policy models toward centralization.

My discussion has been limited to changes in policy models, and I have not considered the possibility that coordinated shifts in personal preferences (and, therefore, in targets and goals) may be an independent cause of discontinuity in public policy. The best known study that attempts to link preferences and changes in public policy probably is Albert Hirschman's book, Shifting Involvement. Private Interest and Public Action (1982), which draws on social psychology to explain a private-public cycle. Hirschman's explanation is based on the notion that exposure 
to consumer goods, especially certain types of durables, creates more comfort than pleasure, and comfort saturates and disappoint consumers, who then turn to other activities, especially to public life, to meet their need for pleasure. Similarly, frustrations of public life eventually saturate actors and send them back to private action and consumerism. According to Hirschman, these cycles are coordinated across nations which enter the phase of mass consumption at about the same time.

Although there is a grain of truth in the Hirschman thesis, I do not consider the phenomenon he discusses to be the fundamental force driving public policy in the 20th century (and probably neither does he), Hirschman began writing his fascinating and insightful study in 1978 stimulated by a puzzle: why the 'Spirit of 1968' had turned into apathy ten years later. He does not explicitly analyze whether these private-public cycles maintain a constant amplitude, explode, or peter out, but there is a presumption of constancy. However, if society is not given repeated impulses of comparable magnitude as the initial entry into mass consumption, it is conceivable that people may learn to balance public and private action, which would dampen the cycles. Further, Hirschman's theory does not recognize that people respond to actual experience with social systems by revising their ideas of how they work. Instead, the move toward statism is motivated only by demand for public action as a consumer good, which may be one of many forces but probably not a dominating one.

\section{The dynamics of regulatory regimes as a dependent variable}

In Section 1, I suggested that uncertainty, and incomplete and variable policy models may initiate regulatory regimes that lock into a path of decline. Now the time has come to elaborate these ideas.

Many of the rules of social interaction arise spontaneously (Sugden, 1989), but other rules are purposive designs. I prefer to frame the decisions of those who attempt to design or manipulate social systems in terms of a policy model, a concept which I borrow from Jan Tinbergen (1956) and the theory of (macro-) economic policy, which emerged after the Second World War (Hansen, 1963). A policy model 
specifies the relationship between two sets of variables: variables that are defined as targets or goals, and variables that are the instruments of policy and are directly controlled by policy makers. Conceptually, there are two categories of policy models: Structural policy models lay down what policy makers must do to create a new control or regulatory regime, for instance for the purpose of ensuring rapid economic growth, providing low cost housing, clean air, or efficient markets. Quantitative policy models show what policy makers need to do, within a given structure, to reach specific goals, for instance what values are required for for tax rates and changes in the money supply to ensure a stable price level, or,-in a stateregulated airline industry, what fares, routes, frequency of service and provision of meals and refreshments on flights give the desired level of service.

In order to explore the dynamics of regulatory regimes, the old theory of economic policy must be modified in three ways (Eggertsson, 1996). First the confidence of post-war (macro-) economics must be replaced by the notion, which this paper has emphasized, that, even among experts, policy models are incomplete and variable, and that policy models change over time. Nothing illustrates my point better than the very history of macroeconomics after the Second World War.

Second, I borrow a central idea from Robert Lucas (1972, 1975,1977), namely the notion that, not only policy makers, but also regular actors rely on policy models to reach their goals within a social system. In his contributions to rational expectations macroeconomics, Lucas often empowers ordinary economic actors with complete (accurate) policy models of the economy and full information, which enables them to anticipate and avoid public policy measures. In the world of this essay, however, information and knowledge are scarce, and rational actors use incomplete data and models to make their decisions, which is not inconsistent with Lucas's approach. ${ }^{5}$

Third, I borrow the idea of multiple valuable margins from the property rights

The rational expectations hypothesis "does not imply that all agents have the same information, or that all agents know the "true" economic model; it simply means that agents use available information in the best way and collect further information only if the expected benefit exceeds the cost." (Svensson, 1996, p. 3.) 
literature, which emphasizes the complexity of control by introducing resources with multiple valuable margins of uses. (Barzel, 1989). In standard price theory with full information, a large number of valuable margins adds nothing new to the analysis. In the property rights literature (and in the new economics of information), which assumes transaction costs, effort to control use at various margins gives rise to contractual arrangements, measurement, enforcement, evasion, waste of resources, and unintended side effects.

The various uses of a building is a good example of what property rights analysis means by multiple valuable margins. By withholding rights to most of the valuable uses of a building, the state can reduce the value of private ownership almost to zero. The value to owners of their buildings also is induced when renters abuse their units (and don't pay compensation), but the task of writing and enforcing a contract which specifies all permissible margins of use is a complex and costly. Finally, attempts by the state to transfer value from landlords to tenants through rent control are fraught with difficulties, because the state must ensure that landlords refrain from reducing the supply of housing services at some valuable margins (for instance, by no longer providing maintenance or heating), and from inventing evasive payment systems such as 'key money'. With information scarcity, the state initially may not know all possible margins of evasion, and similarly, when the state changes the rules of the game, it may take some time for landlords to explore their new opportunities, and discover costs and benefits of alternative strategies. And neither sides at first may understand the aggregate dynamics of a new housing regime, which, under some circumstances, can involve a decline of the housing stock, or premature demolition and rebuilding, and even destabilization of financial markets (Cheung, 1974, 1976).

My point by bringing together incomplete policy models of private and public actors, complexity, interaction, and learning by experience is to provide a framework for analyzing why the initiation of a regulatory regime usually sets in motion a dynamic process. The critical question concerning such dynamic processes, as Kruger (1993) emphasizes is whether, in terms of original targets, the sequence of 
measures-response-results-measures is a virtuous or vicious circle. I refer to institutional regimes that turn bad in terms of original goals as imperfect institutions. In the context of economic theory, all purposive institutional design is imperfect, compared to what the design could be if we relax one or more constraints; and all institutional design is perfect, in the sense of leaving no scope for Pareto improvements, if we define policy choices as optimization under constraints. My definition of imperfect institutions (imperfect control or regulatory regimes) is a retrospective one:

An institutional regime introduced by $\mathrm{A}$ at point $\mathrm{t}$, or existing at point $t$, is imperfect (in retrospect), if A would have we made a categorically different decision at $t$, had it foreseen the path taken by the institutional regime and the sequence of results.

For instance, in the world according to Lucas, a (slow-witted) central authority, A, may learn by trial and error that its instruments cannot systematically affect real macroeconomic magnitudes, and decide that its control regime is imperfect and discard it. My definition, therefore, relaxes the knowledge constraint in this specific sense, and a theory that could to explain the path of institutional regimes would endogenize imperfect institutions, so defined. Our science cannot write history (and once history becomes predictable, A would avoid imperfect institutions), but modern economics and political economy offer various insights, some of which are discussed below.

Imperfect institutions need not become a serious social problem, if rule makers discover serious flaws early and scrap non-reformable arrangements. In practice, imperfect institutions often lock in, persist, and become semi-permanent. ${ }^{6}$ Various factors explain such path dependence:

6 Kruger (1993, 1978), and Bhagwati (1978) provide excellent analysis of sequences of macroeconomic political economic interactions, and cycles of policy-making in developing countries, for instance in the evolution of foreign trade regimes. 
(a) An imperfect regulatory regime moves slowly down a path of increasingly perverse outcomes, when those who operate under the regime adjust their personal policy models and behavior with a long lag. Important adjustment even may have to wait for a new generation of actors. In recent essays, Assar Lindbeck $(1994,1995)$ has analyzed how the Swedish welfare system, although creating virtuous circles of benefits in some areas, went down a perverse path, and increasingly spawned unintended and unwanted side effects. According to Lindbeck, these problems are associated with delayed changes in the behavior of households, interest groups, public sector administrations, and politicians. A description of a perverse path is found also, for instance, in studies of the regulatory regime that governed the US airline industry, 1938-1978. The studies show how the airlines, who had $\backslash$ refrain from price competition, instead competed on various non-price margins, and how that competition gradually spread from one margin to another. Toward the end, attempts by the US Civil Aeronautics Board to control valuable margins involved "writing regulations that defined the size of a coach class seat and the amount of meat that could be lawfully served on a sandwich (Noll, and Owen, 1983, p. 156). The regulatory path created an upward trend in operational costs, and rent-seeking among employees, and, in the end, there was broad political support for deregulation.

(b) Longevity of malfunctioning institutions also is due to delays by the regulators themselves in recognizing the imperfection of their regimes, even after adverse results materialize. Blinded by their incomplete policy models, rule makers often remain optimistic about their ability to control and remedy faults. As poor results become visible, it takes time for the authorities to decide whether an unsatisfactory outcome is a one-time blip, a repairable problem, or a sign that the control regime should be discarded. Decisions are particularly difficult when the previous choice of a regime excluded alternative arrangements and eliminated any opportunity for comparison. Besides, investment in additional knowledge usually centers on aspects of existing institutional regimes rather than on alternative arrangements. Yet, when opportunity for comparison arises, it frequently plays a large role in the recognition of imperfect 
institutions. In the United States, the performance of unregulated intrastate airlines in Texas and California helped convince rule makers that the regime governing the national airlines should be abolished (Vietor, 1990, p. 19). Similarly, the mainstream of the British Conservative Party used examples of state-owned industries abroad to fight nationalization at home. In 1928 a Tory publication noted that "the state railways in Australia were reported to be at the mercy of voracious union leaders and their lazy overpaid members, while the government coal mines in Bulgaria were deemed to be hives of inefficiency (as summarized by Singleton, 1995, p. 19)."

(c) A third reason for the common longevity of imperfect institutions is the frequent asymmetry in institutional change. Policy makers often have considerable freedom of choice when they select a control regime to handle particular situations, but, once a choice has been made, the new regime locks in and policy reversals become difficult, because economic actors have made investments that are specific to the regime. Various forms of support, subsidy, and preferential treatment frequently make actors and organizations dependent on a regime. A serious problem for rule makers emerges when actors make investments that are specific to regimes with unexpected, unwanted, and harmful side effects, and then stand ready to protect their investments. In such circumstances, reforms often are delayed until a high level of dysfunction is reached, and very poor outcomes make non-specialists — the general public — revise their policy models and demand reforms. Winiecki's (1990) account of the rulers' inability to reform the soviet system, which in part hinges on the lack of cooperation from mid-level agents of the state, whose investments were specific to the soviet system, is a good example of this type of path dependence. The same is true of Higgs's (1982) analysis of the dynamic path of regulations governing the salmon fishery in the state of Washington, which brought technical regress and failed to conserve the resource.

(d) Finally, new technology can contribute to the long life of imperfect institutions. Of course,new technologies are hard to predict, but, looking back, regulators might want to reconsider their previous choice and select a flexible but perhaps somewhat inefficient regimes, which could rapidly adjust to the new technology. Again, 
Winiecki (1990), analyzing the soviet system, makes the case that technological change gradually complicated input-output relationships and severely undermined central management, but system-specific investments of mid-level agents prevented the rulers from backing out of the regime that they had instituted in 1928.

The lesson of this section is twofold. First, incomplete models and the dynamics of regulatory regimes suggest that we should find frequent small-scale discontinuity in public policy, when small-scale experiments fail. Imperfect institutions include both centralized and decentralized structures. Second, when historical circumstances invite a surge of great experiments in social organization, a large concentration of imperfect institutions will appear after an appropriate interval as some of these experiments are bound to create vicious circles, while others will survive. The four reasons listed above suggest that it impossible to generalize how long malfunctioning organizations survive, but the formal rejection of failed experiments is likely to have demonstration effects for comparable arrangements at home and abroad, and possibly create a surge of reforms, indicating that the state has changed its mind.

\section{Conclusion}

In this essay I have said little about political coalitions and their role in causing discontinuity in public policy, but instead emphasized visions of social organization that transcend special interest and party politics. In addition, my discussion of policy models did not dwell on the presumption that, in our world of uncertainty and limited knowledge, the human mind often shapes social reality to match narrow personal interests and experience. I also did not mention that for strategic reasons people often falsify their preferences and policy models (Kuran, 1995), and that political expediency often pushes elites to select ineffectual arrangements, not because their basic economic policy model is widely off target, but because such order is their best hold on power. All these considerations I do recognize, although here I have put more emphasis on other issues.

My main conclusion is in two parts, which the reader may find contradictory: I 
argue that the state both knows and does not know what it is doing. Control regimes are motivated not only by redistribution, but also by attempts to solve real problems, and the nature of economic problems varies with the methods of production. The control problems of an agrarian or an early industrial society differ from those of mature industrial or post-industrial communities- The problems of consumer and worker safety, and spillover effects are different at the end of the 20 th century than they were early in the 19th century. Control regimes will reflect these and other differences, and there is no turning back.

On the other hand, our knowledge of how to organize social systems is punier than the confident voice of social science and political entrepreneurs suggests. Institutional design, especially on a large scale, often is no more than speculative experiments. Before it was tried, no one really knew whether a nationalized industry would be a success or not, or whether central management in the Soviet Union would work, although many people held strong beliefs on such issues. In addition, success or failure of public policy often depends on detail that is not visible when we use global categories, such as public/private or market/planning.

The twentieth century has been an age of often disastrous experimentation with different systems to control the forces of production, improve the stock of human capital, create wealth, distribute the yield, and increase well-being. At the end of the epoch, decentralized, democratic states appear to be the winners. So, where do we stand? Are there regular private-public cycles, either short (one generation, for instance) or long (a century)? Will a new long wave of liberalism sweep through the 21st century? My answer is short. I do not think public policy goes through systematic cycles that repeat themselves for ever. Although we discern some regularity in the last 200 years, I see no reason why they will be repeated: the mixture of power politics, technology, industrial organization, and imperfect policy models is too chaotic to create mechanical cycles. I have argued, however, that events such as great depressions, major wars, or traumatic structural change can give rise to large-scale social experiments, which create at least two bumps or discontinuities. First, when new arrangements are introduced, and again when 
imperfect institutions are discarded, but such waves are likely taper off.

Finally, two points. First, it is reasonable to believe that the experiments of the 20th century has taught us lessons that will stick. The most important lesson is the rediscovery of incentives, information problems, and complexity, which at one point was nearly lost both to specialists and the general public, remarkable as it sounds in hindsight. Second, the ongoing information revolution will impact society as profoundly as did the industrial revolution, but no one knows what types of social experiments the new revolution will engender. 
References

Alston, L.J., T. Eggertsson, and D.C. North, eds. 1996: Empirical Studies in Institutional Change. Cambridge: Cambridge University Press.

Alt, J.E., and K.A. Shepsle, eds. (1990). Perspectives on Positive Political Economy. Cambridge: Cambridge University Press.

Atkinson, A., and J.E. Stiglitz (1980). Lectures on Public Economics. Maidenhead: McGraw Hill.

Bairoch, P. 1989. "European Trade Policy, 1815-1914. In Mathias and Pollard (eds), pp. $1-160$.

Barzel, Y. 1989. Economic Analysis of Property Rights. Cambridge: Cambridge University Press.

Bhagwati, J.D. 1978. Foreign Trade Regimes and Economic Development: Anatomy and Consequences of Exchange Control Regimes. Cambridge, MA: Ballinger.

Buchanan, J. M., et al., eds. 1980. Toward a Theory of the Rent-Seeking Society. College Station: Texas A \& M University Press.

Checkland, S.G. (1989). "British Public Policy, 1776-1939." In Mathias and Pollard (eds.), 607-640.

Cheung, S.N.S. 1974. "A Theory of Price Control." Journal of Law and Economics 17: 5371.

Cheung, S.N.S. 1976. "Rent Control and Housing Reconstruction: The Postwar Experience of Prewar Premises in Hong Kong." Journal of Law and Economics 17: 27-53.

Chick, M., ed. 1990. Government, Industries and Markets. Aspects of-GovernmentIndustry Relations in the UK, Japan, West Germany, and the USA since 1945. Aldershot: Edward Elgar.

Coase, R.H. 1991. 'The Institutional Structure of Production." Nobel Memorial Prize Lecture. Reprinted in R.H. Coase (1994). Essays on Economics and Economists, pp. 314 Chicago: University of Chicago Press.

Davies, R.W. 1989. "Economic and Social Policy in the USSR, 1917-1941." In Mathias and Pollard (eds.), pp. 984-1047.

Denzau, A.T., and D.C.North. 1994. "Shared Mental Models: Ideologies and Institutions." Kyklos 47: 3-31.

Eggertsson, T. 1990. Economic Behavior and Institutions. Cambridge: Cambridge University Press.

Eggertsson, T. 1996. "Rethinking the Theory of Economic Policy. Some Implications of the New Institutionalism." Working Paper. Stanford: Hoover Institution.

Ford, A G. 1989. "International Financial Policy and. the Gold Standard 1870-1914." In Mathias and Pollard (eds.), pp. 197-249.

Hall, P.A. 1986. Governing the Economy. The Politics of State Intervention in Britain 
and France. Cambridge, Engl.: Polity Press.

Hansen, B. 1963. Lectures in Economic Theory, Part III: The Theory of Economic Policy. Cairo: United Arab Republic, Institute of Planning.

Higgs, R. 1982. "Legally Induced Technical Regress in the Washington State Salmon Fishery,". Research in Law and Economics 7: 55-86. Reprinted in Alston, et al. (eds.) 1996.

Hirschman, A.O. 1982. Shifting Involvement. Private Interest and Public Action. Princeton: Princeton University Press.

Krueger, A.O. 1978. Foreign Trade Regimes and Economic Development: Liberalization Attempts and Consequences. Cambridge, MA: Ballinger

Krueger, A.O. 1993. Political Economy of Policy Reform in Developing Countries. Cambridge: MIT Press.

Kuran, T. 1995. Private Truths, Public Lies. The Social Consequences of Preference Falsification. Cambridge: Harvard University Press.

Letwin, W. 1989. "American Economic Policy, 1865-1939." In Mathias and Pollard (eds.), pp. 641-690.

Lindbeck, A. 1994. "Overshooting, Reform and Retreat of the Welfare State." De Economist 104: 1-19.

Lindbeck, A. 1995. "Welfare State Disincentives with Endogenous Habits and Norms." Scandinavian Journal of Economics 97: 477-494.

Lucas, R. E. 1972. "Expectations and the Neutrality of Money." Journal of Economic Theory 4: 103-124.

Lucas, R.E. 1975. "Economic Policy Evaluation. A Critique." In K. Brunner, and A. Meltzer (eds.), The Phillips Curve and Labor Markets. Amsterdam: North-Holland. Lucas, R.L. 1977. "Understanding Business Cycles." In K. Brunner and A. Meltzer (eds.), Stabilization of the Domestic and International Economy. Amsterdam: NorthHolland.

Macmillan H. 1938. The Middle Way: A Study in the Problem of Economic and Social Progress in a Free and Democratic Society. London: Macmillan.

Mathias, P., and S. Pollard, eds. 1989. The Cambridge Economic History of Europe. Volume V1I1. The Industrial Economies: The Development of Economic and Social Policies. Cambridge: Cambridge University Press.

McCloskey, D.N. and J.R. Zecher 1976. How the Gold Standard Worked 1880-1813. In J.A. Frenkel, and H.G. Johnson (eds.), The Monetary Approach to the Balance of Payments. Toronto: University of Toronto Press.

Milgrom, P., and J. Roberts (1992). Economics, Organization, and Management. Englewood Cliffs: Prentice Hall.

Moe, T.M. (1990). "Political Institutions: The Neglected Side of the Story." Journal of Law Economics \& Organization 6: 213-254. 
Moggridge, D. E. 1989. 'The Gold Standard and National Financial Policies, 1913-39." In Mathias and Pollard (eds.), pp. 250-314.

Mueller, D.C. (1989). Public Choice II. Cambridge: Cambridge University Press.

Noll, R.G., and B.M. Owen. 1983. "Conclusions: Economics, Politics, and Deregulation." In R.G. Noll, and B.M. Owen (eds.), The Political Economy of Deregulation: Interest Groups in the Regulatory Process. Washington, D.C: American Enterprise Institute.

North, D. C. 1993. "Institutions and Credible Commitment." Journal of Institutional and Theoretical Economics 149:11-23.

North, D.C. 1981. Structure and Change in Economic History. New York: W. W. Norton.

North, D.C. 1990. Institutions, Institutional Change, and Economic Performance. Cambridge: Cambridge University Press.

North, D.C. 1993. "Economic Performance through Time." Nobel Memorial Prize Lecture. Reprinted in Alston, et al. (eds.) 1996:342-356.

North, D.C. and B.R. Weingast (1989). "Constitutions and Commitment: The Evolution of Institutions Governing Public Choice in Seventeenth-Century England. Journal of Economic History 49: 803-832. Reprinted in L.J. Alston, et al. (1996).

Olson, Mancur 1971. The Logic of Collective Action, rev. ed. Cambridge, Mass: Harvard University Press.

Schremmer, D.E. (1989). "Taxation and Public Finance: Britain, France, and Germany. In Mathias and Pollard (eds.), pp. 315-494.

Singleton, J. 1995. Labour, the Conservatives and Nationalization. In R. Millward, and J. Singleton, J. (eds.) The Political Economy of Nationalization in Britain 1920-1950. Cambridge: Cambridge University Press.

Sugden, R. 1989. "Spontaneous Order." Journal of Economic Perspectives, 3: 85-97.

Svensson, L.E.O. 1996. "The Scientific Contributions of Robert E. Lucas, Jr." Scandinavian Journal of Economics 98:1-10.

Tinbergen, J. 1956. Economic Policy: Theory and Design: Amsterdam: New Holland.

United Kingdom, Parliament. 1918. First Interim Report of the Committee on Currency and Foreign Exchange after the War. Cmnd 9182 (The Cunliffe Report).

Vietor, R.H.K. 1990. Regulation and Competition in America, 1920s-1980s. In Chick. Pp. 10-35.

Vietor, R.H.K. 1994. "Contrived Competition: Economic Regulation and Deregulation, 1920s-1980s." Business History 36: 1-32.

Weingast, B. R. 1993. "Constitutions as Governance Structure: The Political Foundations of Secure Markets." Journal of Institutional and Theoretical Economics 149: 286-311.

Weingast, B.R. 1995. 'The Economic Role of Political Institutions: Market Preserving Federalism." Journal of Law and Economics 7: 1-31.

Winiecki, J. 1990. "Why Economic Reforms Fail in the Soviet System: A Property 
Rights-Based Approach." Economic Inquiry 28. Reprinted in Alston, et al: (eds.), 1990. 